удК 661.183.95.

\title{
ПРОДУКТИВНІСТЬ, ЯКІСНИЙ СКЛАД ТА РАДІОАКТИВНІСТЬ МОЛОКА КОРІВ ПРИ ПІДГОДІВЛІ ЇХ КОМПЛЕКСОНАТАМИ МІКРОЕЛЕМЕНТІВ
}

\author{
Біденко Володимир Миколайович \\ кандидат сільськогосподарських наук, доцент \\ Поліський національний університет \\ ORCID: 0000-0002-6763-277X \\ E-mail: volodimerbidenko25@ukr.net
}

Трохименко Віта Зигмундівна

кандидат сільськогосподарських наук, доцент

Поліський національний університет

ORGID: 0000-0002-1763-3141

E-mail: trohimenkovita@ukr.net

Маліцький Віктор Олександрович магістрант

Поліський національний університет

ORGID: 0000-0002-6655-1687

E-mail: malickiyviktor@ukr.net

Маліцька Анна Сергіївна магістрантка

Поліський національний університет ORGID: 0000-0001-7468-6517

E-mail: malickaanna@ukr.net

Дейнека Марина Василівна магістрантка

Поліський національний університет

ORGID: 0000-0001-6975-4036

E-mail: deinekamarina@ukr.net

Пєшкова Наталія Олегівна

магістрантка

Поліський національний університет ORGID: 0000-0002-0253-0641

E-mail: pesckovanataliy@ukr.net

Мікроелементи у житті тварин відіграють надто важливу роль. Вони входять до складу ферментів, гормонів та вітамінів, активують обмінні процеси в їх організмі, сприяють підвищенню продуктивності, покращенню якості отримуваної продукції, підсиленню резистентності. Експериментально встановлено, що мікроелементи здатні вносити певні зміни у метаболізм радіонуклідів. Між мікроелементами і радіонуклідами в організмі тварин можуть виникати складні конкурентні відносини, блокування засвоєння і переходу останніх в організм та їх продукцію. Дослідження нами були проведені у господарстві СТОВ «Полісся» Народицького району Житомирської області на дійних коровах відібраних у 3-и групи по п'ять голів у кожній по принципу пар-аналогів. Тварини 1-ї контрольної групи отримували господарський раціон. Корови 2-ї групи, крім господарського раціону комплексонати мікроелементів цинку у підвищеній кількості, марганцю у нормовані кількості, 3-ї групи у нормовані кількості цинку, марганцю, міді. У результаті проведення експерименту встановлено, що надій корів 2-ї та 3-ї дослідних груп по відношенні до 1-ї контрольної групи був вищим 12 і 10\%, відповідно. Введення комплексонатів мікроелементів раціони корів 2-ї та 3-ї групи сприяло зниженню питомої активності молока корів за ${ }^{137} \mathrm{Cs}$ в 1,8 і 1,3 рази, за ${ }^{00} \mathrm{Sr}$, в 1,6 i 1,3 рази, відповідно. У молоці корів дослідних груп відмічалася тенденція зниження концентрації важких металів, свинцю і кадмію.

Ключові слова: корови, продуктивність, раціон, мікроелементи, комплесонати, радіонукліди.

DOI: https://doi.org/10.32845/bsnau.lvst.2021.4.9

На Поліссі Житомирщини, у раціонах корів, відповідно їх організмі спостерігається нестача по багатьох мінеральних речовинах - мікроелементах, зокрема міді, кобальту, йоду, марганцю, цинку і селену [1]. Незважаючи на здатність організму тварин регулювати постійність мінерального скла-

ду, часто при інтенсивному їх використанні можливості цих регуляторних механізмів $€$ недостатніми і відповідно не ефрективними для підтримання внутрішнього гомеостазу. При цьому, як наслідок в організмі порушується функціональна діяльність органів і систем, виникають хвороби обміну 
речовин, проходять зміни у процесах відтворення, народжується слабий приплід, знижується продуктивність дорослих тварин, погіршується якість отримуваної продукції, збільшуються затрати кормів на утворення продукції, її собівартість [2]. Нестача мікроелементів в організмі знижує природну резистентність, призводить до виникнення ряду захворювань, однією із яких є мікроелементози тварин [3]. Особливо це стосується зони радіоактивного забруднення, північного регіону Житомирщини, у кормах та раціонах тварин якого відмічається значна нестача вищевказаних мінеральних елементів [4]. Крім того, важливість підгодівлі тварин мікроелементами у зоні радіоактивного забруднення в тому, що останні здатні взаємодіяти із радіонуклідами, блокувати засвоєння їх у шлунковому каналі, знижувати перехід у продукцію [5]. За даними І. М. Гудкова [6], мікроелементи до радіонуклідів виступають у ролі радіоблокаторів. Вони позитивно впливають на покращення імунного статусу організму тварин, що особливо важливо на території радіоактивного забруднення, при дії на організм радіаційного чинника. Для поповнення раціонів тварин дефіцитними елементами їх підгодовують преміксами, або солями металів, а також вводять хелатні сполуки мікроелементів. Інститутом загальної та неорганічної хімії ім. В. І. Вернадського були синтезовані комплексонати металів, комплексоном яких була етилендиаміндибурштинова кислота (Edds). До її складу включали метали: мідь, кобальт, марганець, цинк [7, 8]. Так, як у рослинництві добре себе проявив мікроелемент цинк у вигляді комплексонату щодо зниження радіоактивності продукції рослинництва, метою нашої роботи було дослідити вплив різних комплексонатів мікроелементів, кобальту, міді, марганцю, цинку у підвищених кількостях, їх поєднанні на якісний склад молока корів, продуктивність, перехід ${ }^{137} \mathrm{Cs}$ i ${ }^{90} \mathrm{Sr}$ iз раціону в молоко тварин.

Після аварії на ЧАЕС було проведено ряд досліджень по вивченню впливу солей мікроелементів на продуктивність корів, перехід ${ }^{137} \mathrm{Cs}$ із раціону в молоко тварин [9, 10, 11, 12]. Проте практично відсутні дані по дослідженню впливу хелатних сполук мінералів на продуктивні якості тварин, перехід радіонуклідів ${ }^{137} \mathrm{Cs}$ i ${ }^{90} \mathrm{Sr}$ із кормів раціону в молоко.

Матеріали та методи досліджень. Дослідження проводилися у с. Селець Народицького району на молочнотоварній фермі, дійних коровах. Для цього на фермі було відібрано 15 голів корів, сформованих у 3-и групи по принципу пар-аналогів, по п'ять голів у кожній. Дослід проводився за схемою, таблиця 1.

При активізації обмінних процесів в організмі краще засвоюються поживні і мінеральні речовини, відповідно поліпшується якість отримуваної продукції.

\section{Схема досліду}

Таблиця 1.

\begin{tabular}{|c|c|c|c|c|}
\hline \multicolumn{5}{|r|}{ ט } \\
\hline $\begin{array}{l}\text { № } \\
\text { ח/ }\end{array}$ & $\begin{array}{c}\text { Групи } \\
\text { тварин }\end{array}$ & Порода & $\begin{array}{c}\text { Кількість } \\
\text { голів }\end{array}$ & Умови годівлі тварин \\
\hline 1. & 1 контр & Укр. чорно-ряба & 5 & ОР - основний господарський раціон (концентровані корми, трава пасовищна, трава підгодівлі) \\
\hline 2. & 2 & $-\ll-\ll--\ll-\ll-$ & 5 & OP + Edds Zn (на 70\% вище норми), Mn (100\% норми) \\
\hline 3. & 3 & $-\ll-\ll--\ll-\ll-$ & 5 & OP + Edds Zn, Mn, Cu (100\% норми) \\
\hline
\end{tabular}

Вищевказані комплексонати мікроелементів тваринам згодовували з концетрованими кормами. Один раз у місяць проводили контрольний удій, при проведенні якого відбирали проби молока на аналіз, пропорційно добового надою. Вміст жиру і білка у молоці корів визначали на приладі «Екомілк». Кальцій - трилонометричним методом, фосфор - із застосуванням молібдено-ванадієвого амонію з послідуючим колориметруванням. Мікроелементи залізо, кобальт, марганець, цинк, мідь, а також важкі метали сви- нець і кадмій визначали на атомноадсорбційному спектрометрі, ${ }^{137} \mathrm{Cs}$ - на приладі PI-БГ. Для визначення ${ }^{90} \mathrm{Sr}$ у молоці корів попередньо проводили спалювання зразків з утворенням золи, а далі визначали вміст ізотопу на приладі РІ-БГ.

Результати досліджень. Мікроелементи активуючи обмінні процеси в організмі тварин сприяють підвищенню їх молочної продуктивності. Дані по надою корів дослідних груп представлені у таблиці 2.

Молочна продуктивність дослідних корів

Таблиця 2.

\begin{tabular}{|c|c|c|c|c|c|c|c|}
\hline \multirow[b]{2}{*}{ Показники } & \multirow[b]{2}{*}{$\begin{array}{c}\text { Групи } \\
\text { корів }\end{array}$} & \multicolumn{6}{|c|}{ Місяці досліду } \\
\hline & & 1 & 2 & 3 & 4 & 5 & $\begin{array}{c}\text { Надоєно за } \\
\text { дослід, кг }\end{array}$ \\
\hline \multirow{3}{*}{ Надій молока, кг } & 1 & $303,0 \pm 13,0$ & $348,4 \pm 8,9$ & $289,8 \pm 6,18$ & $217,0 \pm 11,6$ & $186,0 \pm 16,2$ & 1344,2 \\
\hline & 2 & $315,0 \pm 15,2$ & $372,6 \pm 11,3$ & $339,0 \pm 14,5$ & $243,0 \pm 13,3$ & $229,4 \pm 14,3$ & 1499,0 \\
\hline & 3 & $303,0 \pm 21,5$ & $363,9 \pm 12,7$ & $316,8 \pm 18,7$ & $226,9 \pm 14,1$ & $263,5 \pm 12,8$ & 1474,1 \\
\hline \multirow{3}{*}{$\begin{array}{l}\text { Середньодобовий } \\
\text { надій на корову, кг }\end{array}$} & 1 & $10,1 \pm 0,63$ & $11,2 \pm 0,45$ & $9,7 \pm 0,12$ & $7,0 \pm 0,11$ & $6,0 \pm 0,27$ & \\
\hline & 2 & $10,5 \pm 0,76$ & $12,0 \pm 0,67$ & $11,3 \pm 0,23$ & $7,8 \pm 0,33$ & $7,4 \pm 0,65$ & \\
\hline & 3 & $10,1 \pm 0,52$ & $11,2 \pm 0,66$ & $10,6 \pm 0,24$ & $7,3 \pm 0,45$ & $8,5 \pm 0,55$ & \\
\hline \multirow{3}{*}{ Відсотки } & 1 & 100 & 100 & 100 & 100 & 100 & 100 \\
\hline & 2 & 104 & 107 & 116 & 111 & 123 & 112 \\
\hline & 3 & 100 & 100 & 109 & 104 & 142 & 110 \\
\hline
\end{tabular}

Із даних таблиці видно, найвищу продуктивність за дослідний період мали корови 2-ї дослідної групи - 1499,0 кг, які отримували нормовану кількість марганцю та збагачену цинку. Надій молока у цій групі був вищий ніж у контролі на $12 \%$, при $\mathrm{P}>0,05$. Більшим на $10 \%$ було отримано надій у корів 3-ї групи, надій за дослід становив - 1474,1 кг, тоді як у тварин 1-ї контрольної групи він склав лише - 1344,2 кг $(P>0,05)$.

Отже, надій корів 2-ї та 3-ї групи, які отримували комплексонати мікроелементів міді, марганцю та цинку порівняно із 1-ю контрольною групою були вищими на 10 і 12\%. У таблиці 3. наведені дані якісного складу молока корів. 
Таблиця 3

Якісний склад молока дослідних корів

\begin{tabular}{|c|l|c|c|c|c|}
\hline $\begin{array}{c}\text { №№ } \\
\text { п/п }\end{array}$ & \multicolumn{1}{|c|}{ Групи корів } & Жир, \% & Білок, \% & Са & P \\
\hline 1. & Контроль & $3,59 \pm 0,98$ & $3,08 \pm 0,06$ & $1,07 \pm 0,05$ & $1,08 \pm 0,01$ \\
\hline 2. & Комплексонати мікроелементів $\mathrm{Zn}, \mathrm{Mn}$ & $3,92 \pm 0,09$ & $3,14 \pm 0,06$ & $1,23 \pm 0,02$ & $1,17 \pm 0,04$ \\
\hline 3. & Комплексонати мікроелементів $\mathrm{Zn}, \mathrm{Mn}, \mathrm{Cu}$ & $3,79 \pm 0,31$ & $3,05 \pm 0,05$ & $1,18 \pm 0,03$ & $1,07 \pm 0,05$ \\
\hline
\end{tabular}

Із даних таблиці видно, що збагачення раціонів корів на мікроелементи цинк, марганець, мідь за рахунок комплесонатів сприяло покращенню якості молока корів за рахунок жиру, відсоток якого у молоці корів 2-ї групи збільшився 3 3,59 \% у контролі, до 3,92 \% у молоці корів 2-ї дослідної групи і у молоці корів 3-ї групи був ще вищим на 0,2\%, становив $-3,79 \%$. Тенденція збільшення вмісту білка спостерігалася лише у молоці корів 2-ї групи. Якщо у корів 1-ї контрольної групи вміст становив - 3,08 \%, то у молоці тварин 2ї групи він складав - 3,14\%, при $\mathrm{P}>0,05.3$ мінеральних речовин відмічалася тенденція збільшення кількості кальцію, у молоці корів 1-ї групи вміст його становив - 1,07, у молоці корів 2-ї групи - 1,23, і тварин 3-ї групи - 1,18. Щодо фоссфору спостерігалася тенденція збільшення кількості його лише у молоці корів 2-ї групи - 1,17, у молоці корів 1-ї групи складав $-1,08$.

Отже, введення комплексонатів мікроелементів цинку, марганцю, міді сприяло покращенню якості молока корів 2-ї та 3-ї групи за рахунок жиру, 2-ї групи - за рахунок білка, мінеральних речовин кальцію і фосфору у молоці тварин 2-ї групи.

У таблиці 4. представлені дані мінерального складу молока корів.

Вміст мікроелементів і важких металів у молоці корів, мг/л

\begin{tabular}{|c|c|c|c|c|c|c|c|c|}
\hline $\begin{array}{c}\text { № } \\
\text { п/п }\end{array}$ & Групи корів & $\mathrm{Fe}$ & $\mathrm{Co}$ & $\mathrm{Mn}$ & $\mathrm{Cu}$ & $\mathrm{Zn}$ & $\mathrm{Pb}$ & $\mathrm{Cd}$ \\
\hline 1. & Контроль & 2,74 & 0,07 & 0,25 & 0,31 & 3,83 & 0,32 & 0,034 \\
& & $\pm 0,02$ & $\pm 0,003$ & $\pm 0,01$ & $\pm 0,02$ & $\pm 0,03$ & $\pm 0,020$ & $\pm 0,03$ \\
\hline 2. & Комплексонати & 2,75 & 0,08 & 0,33 & 0,32 & 4,20 & 0,23 & 0,033 \\
& мікроелементів Zn, Mn & $\pm 0,05$ & $\pm 0,003$ & $\pm 0,01^{*}$ & $\pm 0,01$ & $\pm 0,057^{* *}$ & $\pm 0,03$ & $\pm 0,01$ \\
\hline 3. & Комплексонати & 2,85 & 0,08 & 0,33 & 0,36 & 4,16 & 0,25 & 0,027 \\
& мікроелементів Zn, Mn, Cu & $\pm 0,03^{*}$ & $\pm 0,003$ & $\pm 0,02$ & $\pm 0,03$ & $\pm 0,13$ & $\pm 0,03$ & $\pm 0,01$ \\
\hline
\end{tabular}

Дані таблиці свідчать, що у молоці корів дослідних 2ї та 3-ї груп у порівнянні із тваринами 1-ї контрольної групи спостерігалася тенденція збільшення кількості мікроелементів марганцю, міді, цинку, які додавали у раціони тварин. Так, у молоці корів 1-ї групи вміст марганцю становив - 0,25 мг/кг, у молоці тварин 2-ї групи - 0,33 мг/кг, у корів 3-ї групи - 0,33 мг/кг. Відмічалася тенденція збільшення кількості міді, у молоці контрольних тварин становила - 0,31 мг/кг, у молоці корів 3-ї групи становила - 0,36 мг/кг. Істотне збільшення спостерігалося вмісту цинку, у молоці корів контрольних тварин вміст становив - 3,83 мг/кг, у тварин 2-ї групи - 4,2 мг/кг (P<0,01), корів 3-ї групи -4,16 мг/кг.
Щодо важких металів відмічалася тенденція зменшення кількості свинцю та кадмію, у молоці корів 1-ї групи вміст становив - 0,32 мг/кг, у молоці тварин 2-ї групи - 0,23 мг/кг, 3-ї групи - 0,25 мг/кг, кадмію - у молоці тварин 1-ї групи - 0,034, 2-ї групи - 0,033, 3-ї групи - 0,027 мг/кг.

Введення комплексонатів мікроелементів у раціони корів 2-ї та 3-ї групи сприяло покращенню якості молока тварин за рахунок мікроелементів міді, марганцю, цинку, та зменшенню вмісту свинцю, кадмію.

У таблиці 5. представлені дані питомої активності молока корів за ${ }^{137} \mathrm{Cs}$ i ${ }^{90} \mathrm{Sr}$.

Вміст ${ }^{137} \mathrm{Cs}$ і ${ }^{90} \mathrm{Sr}$ у молоці дослідних корів, Бк/л

Таблиця 5

\begin{tabular}{|c|c|c|c|c|c|c|c|}
\hline \multirow[b]{2}{*}{$\begin{array}{l}\text { № } \\
\text { ח/ח }\end{array}$} & \multirow[b]{2}{*}{ Групи корів } & \multicolumn{3}{|c|}{${ }^{137} \mathrm{Cs}$} & \multicolumn{3}{|c|}{$90 \mathrm{Sr}$} \\
\hline & & Бк/л & $\begin{array}{l}\% \text { до } \\
\text { контр. }\end{array}$ & $\begin{array}{l}\text { Кратністьзниження } \\
\text { радіоактив., разів }\end{array}$ & Бк/л & \% до контр. & $\begin{array}{l}\text { Кратність зниження } \\
\text { радіоактив., разів }\end{array}$ \\
\hline 1. & Контроль & $196 \pm 7,8$ & 100 & - & $14 \pm 0,13$ & 100 & - \\
\hline 2. & $\begin{array}{c}\text { Комплексонати } \\
\text { мікроелементів Zn, Mn }\end{array}$ & $110 \pm 15$ & 56 & 1,8 & $9,0 \pm 0,52$ & 64 & 1,6 \\
\hline 3. & $\begin{array}{c}\text { Комплексонати } \\
\text { мікроелементів Zn, Mn, Cu }\end{array}$ & $148 \pm 6,0$ & 76 & 1,3 & $9,2 \pm 0,15$ & 66 & 1,5 \\
\hline
\end{tabular}

Аналізуючи дані таблиці можна зробити наступний висновок, що випасання корів проводилося на угіддях щільність забруднення яких була вищою $10 \mathrm{Ki} / \mathrm{KM}^{2}$ за ${ }^{137} \mathrm{Cs}$, а тому радіоактивність молока за даним ізотопом перевищувала ДР-2006, за ${ }^{90} \mathrm{Sr}$ була в межах допустимих рівнів і складала - 14 Бк/л.

Введення у раціон корів комплексонатів мікроелементів міді та марганцю сприяло зниженню питомої активності молока за радіоцезієм на 44\%, або в 1,8 рази, а при введенні комплексонатів цинку, марганцю та міді на $24 \%$, в 1,3 рази
$(P>0,05)$.

Відмічалася тенденція зниження і вмісту радіостронцію у молоці корів 2-ї та 3-ї дослідних груп, у раціони яких вводили комплексонати мікроелементів, кратність зниження питомої активності за даним ізотопом склала - 1,6 і 1,5 рази, відповідно.

Висновки. Підгодівля молочних корів комплексонатами мікроелементів цинку, марганцю, міді сприяла підвищенню молочної продуктивності тварин на 10 і $12 \%$, при $\mathrm{P}>0,05$. У молоці корів спостерігалася тенденція підвищення 
вмісту жиру та елемента кальцію.

У молоці корів дослідних 2-ї та 3-ї груп відмічалося істотне збільшення вмісту мікроелементів цинку, у молоці корів 1-ї групи вміст становив - 3,83 мг/л, 2-ї групи - 4,20 мг/л (P<0,01), молоці тварин 3-ї групи - 4,16 мг/л $(\mathrm{P}>0,05)$.

Спостерігалася тенденція зниження вмісту важких металів у молоці корів дослідних груп, яким вводили мікроелементи, у молоці корів 1-ї групи вміст становив по свинцю - 0,32 мг/л, тварин 2-ї та 3-ї групи, 0,23 і 0,25 мг/л, відповід- но, по кадмію, у молоці тварин 1-ї групи - 0,034 мг/л, корів 2ї і 3-ї групи, 0,033 і 0,027 мг/л.

Зниження питомої активності молока за ${ }^{137} \mathrm{Cs}$ у корів 2-ї групи становило в 1,8 рази, яких підгодовували підвищеною кількістю цинку, та нормованою за марганцем, 3-ї групи - в 1,3 рази, при підгодівлі їх нормованою кількістю міді, марганцю та цинку. Тенденція зниження питомої активності молока корів за ${ }^{90} \mathrm{Sr}$ становила в 1,6 рази у 2-й групі і 1,3 рази, у 3-й групі.

\section{Список використаної літератури:}

1. Кліценко Г. Т., Кулик М. Ф., Косенко М. В. та ін. Мінеральне живлення тварин. Київ, «Світ». 2001. 575 с.

2. Савчук І. М., Пелехатий М. С., Басаргін В. А. та ін. Годівля та розведення тварин. Житомир 2017. 491 с.

3. Судаков М. О., Береза В. І., Погурський В. Г. та ін. Мікроелементози сільскогосподарських тварин. Київ. Урожай. 1991. $144 \mathrm{c}$.

4. Гудков І. М., Віннічук М. М. Сільськогосподарська радіобіологія. Житомир. 2003. 470 с.

5. Гудков І. М. Радіобіологія. Херсон ОЛДІ-ПЛЮС. 2016. 499 с.

6. Гудков І. М., Грисюк С. М., Лазарєв М. М. і ін. Звіт про науково-дослідну роботу «Вивчити механізми взаємодії стронцію-90 та цезію-137 і мікроелементів з метою розробки прийомів мінімізації надходження цих радіонуклідів в кормові рослини і організм сільськогосподарських тварин. Київ. 2004. 116 с.

7. Трунова Е. К., Мазуренко Е. А., Роговцев А. А. и др. Новый экологически чистый комплексон как хелатирующий реактив. Применение в различных областях прмышленности. Хімічна промисловість. Україна. 2006. № 5. С. 19 - 22.

8. Гудков І. М., Грисюк С. М., Кіцно В. О. та ін. Зменшення надходження ${ }^{137} \mathrm{Cs}$ i ${ }^{90} \mathrm{Sr}$ в сільськогосподарські рослини під впливом мікроелементів. Науковий вісник НАУ. 1998. Вип. 10. С. 264 - 269.

9. Соболев А. С., Асташева Н. П., Пристер Б. С. Метаболизм микроэлементов в организме животных на территории хозяств с повышеным уровнем радиоактивного загрязнения. Тезы док. 1 Всесоюз. Конферен. Самарканд: СГУ. 1990.226 с.

10. Биденко В. Н., Гудков И. Н. Применение комплексонатов микроэлементов в качестве добавок к рациону коров с целью снижения радиоактивности молока. VI съезд по радиационным исследованиям. Тезисы докладов от 25-28 октября, том 2. Москва, 2010. 79 с.

11. Романчук Л. Д. Радіоекологічна оцінка раціонів з різним рівнем мікроелементів як засобу зниження надходження цезію-137 в організм жуйних: автореф. дис. ... канд. с.-г. наук : м. Житомир, 1996. 24 с.

12. Біденко В., Трохименко В., Антонюк В., Галицький П. Зміни радіоактивності молока та продуктивності корів при застосуванні у годівлі комплексонатів мікроелементів міді, марганцю, цинку. Вісник Сумського національного аграрного університету. Серія: Тваринництво, Вип. 2 (41). 2020 с. 24-28 (DOI: https://doi.org/10.32845/bsnau.Ivst.2020.2.4)

\section{References:}

Svit.

1. Klitsenko H. T., Kulyk M. F. and Kosenko M. V., 2001. Mineralne zhyvlennia tvaryn [Mineral nutrition of animals]. K. :

2. Savchuk I. M., Pelekhatyi M. S. and Basarhin V. A., 2017. Hodivlia ta rozvedennia tvaryn [Feeding and breeding animals]. Zhytomyr.

3. Sudakov M. O., Bereza V. I. and Pohurskyi V. H., 1991. Mikroelementozy silskohospodarskykh tvaryn [Microelementosis of farm animals]. K. : Urozhai.

4. Hudkov I. M. and Vinnichuk M. M., 2003. Silskohospodarska radiobiolohiia. [Agricultural radiobiology]. Zhytomyr.

5. Hudkov I. M., 2016. Radiobiolohiia [Radiobiology]. K. : OLDI-PLIUS.

6. Hudkov I. M., Hrysiuk S. M. and Lazariev M. M., 2004. Zvit pro naukovo-doslidnu robotu «Vyvchyty mekhanizmy vzaiemodii strontsiiu-90 ta tseziiu-137 i mikroelementiv z metoiu rozrobky pryiomiv minimizatsii nadkhodzhennia tsykh radionuklidiv $\mathrm{v}$ kormovi roslyny i orhanizm silskohospodarskykh tvaryn» [Research report "To study the mechanisms of interaction of strontium-90 and cesium-137 and trace elements in order to develop techniques to minimize the entry of these radionuclides into forage plants and the body of farm animals]. Kyiv.

7. Trunova E. K., Mazurenko E. A. and Rohovtsev A. A., 2006. Novыi эkolohychesky chystbi komplekson kak khelatyruiushchyi reaktyv. Prymenenye $v$ razlychnыkh oblastiakh prmbshlennosty [New environmentally friendly complex as a chelating reagent. Application in various fields of industry]. Khimichna promyslovist. Ukraina, no. 5, pp. 19-22.

8. Hudkov I. M., Hrysiuk S. M. and Kitsno V. O., 1998. Zmenshennia nadkhodzhennia 137Cs i 90Sr v silskohospodarski roslyny pid vplyvom mikroelementiv [Reduction of $137 \mathrm{Cs}$ and $90 \mathrm{Sr}$ intake in agricultural plants under the influence of microelements]. Naukovyi visnyk NAU, issue 10, pp. $264-269$.

9. Sobolev A. S., Astasheva N. P. Pryster B. S., 1990. Metabolyzm mykrołlementov v orhanyzme zhyvotnыkh na terrytoryy khoziastv s povыshenыm urovnem radyoaktyvnoho zahriaznenyia [Metabolism of microelements in the body of animals on the territory of farms with high levels of radioactive contamination]. Tezы dok. 1 Vsesoiuz. Konferen. Samarkand: SHU., pp. 226.

10. Bydenko V. N. and Hudkov Y. N., 2010. Prymenenye kompleksonatov mykrołlementov v kachestve dobavok $k$ ratsyonu korov s tseliu snyzhenyia radyoaktyvnosty moloka [The use of trace elements of trace elements as additives to the diet of cows to reduce the radioactivity of milk]. VI sъezd po radyatsyonnum yssledovanyiam, Moscow, october 25-28, 2010, vol 2, pp. 79.

11. Romanchuk L. D., 1996. Radioecological assessment of diets with different levels of trace elements as a means of re- 
ducing the intake of cesium-137 in the body of ruminants: Abstractof Ph.D. dissertation. Zhytomyr.

12. Bidenko V., Trokhymenko V., Antoniuk V. and Halytskyi P., 2020. Zminy radioaktyvnosti moloka ta produktyvnosti koriv pry zastosuvanni u hodivli kompleksonativ mikroelementiv midi, marhantsiu, tsynku [Changes in radioactivity of milk and productivity of cows at application in feeding of complexants of microelements of copper, manganese, zinc]. Visnyk Sumskoho NAU. Seriia «Tvarynnytstvo», issue 2(41), pp. 24-28. DOI: https://doi.org/10.32845/bsnau.lvst.2020.2.4

Bidenko Volodymyr Mykolaiovych, PhD in Agriculture, Associate Professor

Trokhymenko Vita Zyhmundivna, PhD in Agriculture, Associate Professor

Malitskyi Viktor Oleksandrovych, Master's student of Polissya National University

Malitska Anna Serhiivna, Master's student of Polissya National University

Deineka Maryna Vasylivna, Master's student of Polissya National University

Pieshkova Nataliia Olehivna, Master's student of Polissya National University

Polissya National University (Zhytomyr, Ukraine)

Productivity, qualitative composition and radioactivity of cow's milk when feeding them with microelement complexonates.

Trace elements in the lives of animals play a very important role. They are part of enzymes, hormones and vitamins, activate metabolic processes in their body, increase productivity, improve the quality of products, increase resistance. It has been experimentally established that microelements are able to make certain changes in the metabolism of radionuclides. Between micronutrients and radionuclides in the body of animals can be a complex competitive relationship, blocking the assimilation and transition of the latter into the body and their products. We conducted research in the farm STOV "Polissia" Narodytsky district of Zhytomyr region on dairy cows selected in 3 groups of five heads in each on the principle of pairs of analogues. Animals of the 1 st control group received a diet. Cows of the 2 nd group, in addition to the economic diet, complexate zinc trace elements in increased quantities, manganese in normalized quantities, 3rd group in normalized quantities of zinc, manganese, copper. As a result of the experiment, it was found that the hopes of cows of the 2nd and 3rd experimental groups in relation to the 1 st control group were higher by 12 and $10 \%$, respectively. The introduction of complexes of trace elements in the diets of cows of the 2 nd and 3 rd groups contributed to the reduction of the specific activity of cow's milk at $137 \mathrm{Cs}$ by 1.8 and 1.3 times, by $90 \mathrm{Sr}$, by 1.6 and 1.3 times, respectively. In the milk of cows of the experimental groups there was a tendency to reduce the concentration of heavy metals, lead and cadmium.

Key words: cows, productivity, diet, microelements, complexants, radionuclides.

Дата надходження до редакції: 15.10.21. p. 